\title{
Rodent Ulcer: A Non-Melanotic Cutaneous Cancer
}

\section{Gaurav A. Thakare*, Nitin Bhola , Nupoor Deshpande , Chinmay Ghavat}

Department of Oral and maxillofacial Surgery, Sharad Pawar Dental College, Sawangi, Maharashtra, India

*Corresponding Author: Gaurav Ashok Thakare, Department of Oral and maxillofacial Surgery, Sharad Pawar Dental College, Sawangi, Maharashtra, India.
Received: March 29, 2020

Published: June 03, 2020

(c) All rights are reserved by Gaurav $\mathbf{A}$

Thakare., et al.

\section{Abstract}

Basal cell carcinoma (BCC) is a cutaneous malignancy. In the past, the term 'Rodent ulcer' has been used to describe this lesion based on its clinically appearance. The lesions most commonly occur on the sun exposed areas of the face, however, BCC of the extremities and genital regions are also noted in the literature. The disease has a low metastasis rare, however, the recurrence following excision is high. A periodic follow up of the patient is required. We present a case of Basal Cell Carcinoma affecting the cheek, which was treated by Moh's micrographic surgery.

Keywords: Basal Cell Carcinoma (BCC); Rodent Ulcer

\section{Introduction}

Basal cell carcinoma is a slow-growing, locally invasive malignant epidermal skin tumour predominately affecting Caucasians [1].

\section{Case Report}

A 50 year old woman, reported to Oral Surgery OPD, SPDC, with the chief complain of a non-healing ulcer over left side of face from 5 years. She gave a history of a small nodular growth which gradually increased to present size of $3 \times 2 \mathrm{cms}$ approximately. On examination, there was a single, large ulcerative lesion present on the left side of face, with ill-defined and rolled out edges, with pinkish red in colour. There was history of bleeding from the lesion (Figure 1). A differential diagnosis of psoriasis, eczema, actinic keratosis, melanocytic nevi, lichenoid benign keratosis and nevus was formulated.

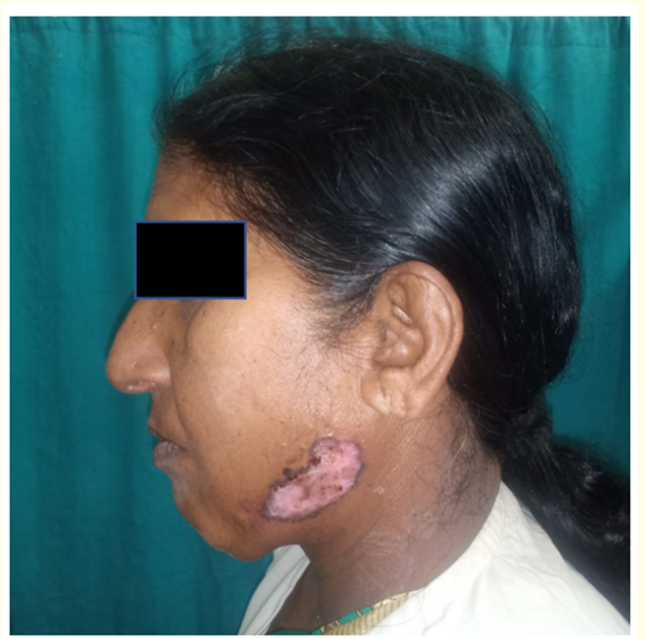

Figure 1
The patient gave a history of incisional biopsy from the lesion 3 years back, for which the r/s/o Basal cell carcinoma. The patient took ayurvedic treatment for same, which provided no relief to her. She then visited to SPDC, after noticing the increase in size, where an MRI was done and biopsy was planned for.

The MRI report was suggestive of a subtle thickening of the soft tissue seen around the left body and ramus of mandible with diffuse subcutaneous oedema and subtle enhancement consistent with the overlying ulcerative lesion. The underlying cortical margin of the mandible appears to be preserved with normal marrow signal intensity (Figure 2).

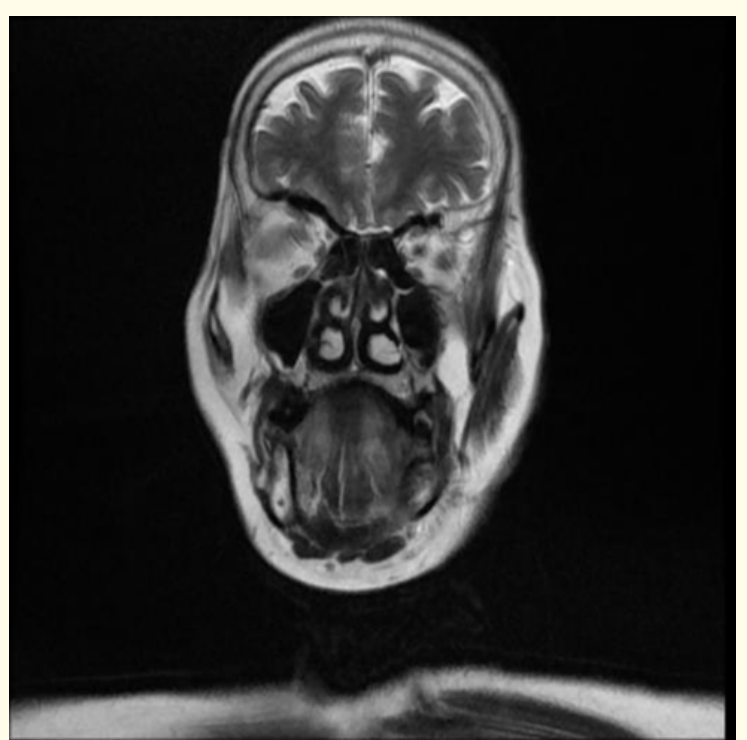

Figure 2 
The incisional biopsy showed keratinized stratified squamous epithelium of varying thickness with melanin pigment in the basal layer. The basaloid cells were invading the dermis in the form of solid nodules. The underlying connective tissue stroma showed bundles of collagen fibres and fibroblasts.

Based on the MRI findings and biopsy report, Mohs micrographic surgery was planned for the patient. Under general anaesthesia, wide local excision of the lesion was carried out. The margins were sent for Frozen section analysis and the resection was carried out till clear surgical margins were achieved. The margins were achieved at a distance of $1 \mathrm{~cm}$ and the defect created was closed using local advancement flap. The excised specimen was sent for histopathological examination.

The histological section showed overlying keratinized stratified squamous epithelium of varying thickness with melanin pigment in the basal cell layer. The basaloid cells were invading the dermis in the form of solid nodules. The underlying connective tissue stroma showed bundles of collagen fibres and fibroblasts. The anterior, posterior, superior and inferior skin margins were free from tumour invasion (Figure 3).

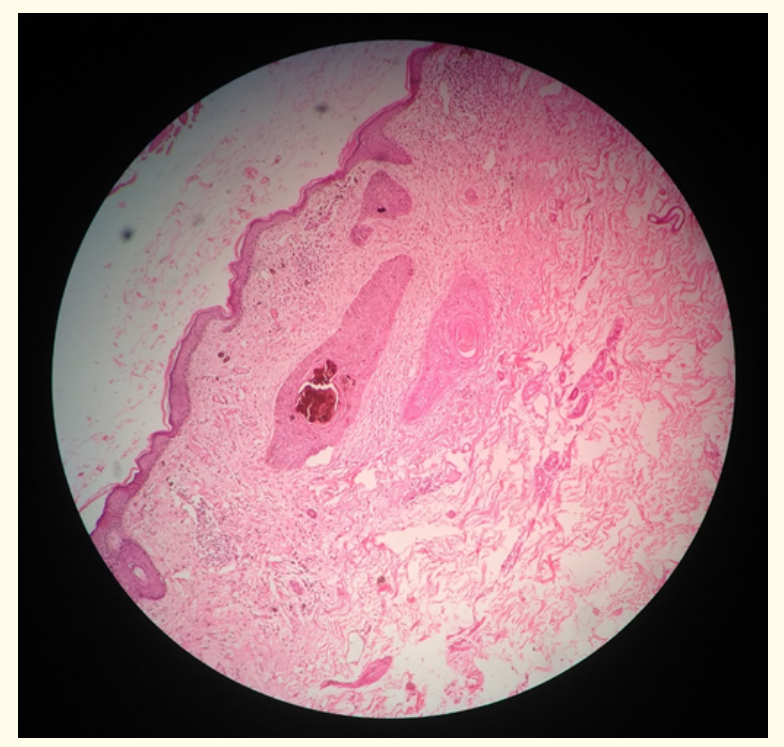

Figure 3

The patient was kept on a follow up of 3 years and no local recurrence or distant metastasis was noted.

\section{Discussion}

Basal cell carcinoma is a slow-growing, locally invasive malignant epidermal skin tumour predominately affecting Caucasians [1]. Jacod Arthurin in 1827 coined the term 'Rodent ulcer' describing its clinical appearance of a burrowed lesion [2]. These account for $1-2 \%$ of the cutaneous lesions in the Indian subcontinent, as compared to the $1 / 3^{\text {rd }}$ affecting the Caucasian populations.
It is a cutaneous malignancy derived from the basal cells of the epidermis and/or hair follicles. BCC mainly affects the photo exposed areas such as the face, trunks and limbs. The lesions may also occur on the genitals and perianal areas. This correlates with the embryonic fusion planes that supports its pathogenesis hypothesis $[3,4]$.

Ultraviolet radiation, UV-B, is the most important etiopathogenic factor for BCC. Intermittent periods of intense sun exposure instead of cumulative exposure is said to have increased the risk for BBC [5]. Ionizing radiation, arsenic exposure, immunosuppression, industrial chemical substances like vinyl chloride, aromatic hydrocarbons, alkalizing agents are the other predisposing factors noted in the literature [6]. BCC is also associated with syndromes like Naevoid Basal Cell Carcinoma, Xeroderma pigmentosum, Congenital basal cell epitheliomas [2]

Clinically, BCC may presents as nodular, cystic, sclerodermiform, infiltrative, micronodular, superficial and pigmented forms. The present case is a superficial spreading variant of basal cell carcinoma. This variant accounts for $10-30 \%$ of the BCC variants. The Superficial BCC does not have infiltration of the tumour cells in the reticular dermis $[5,6]$.

Surgery is the first line of treatment for BCC. The excision of the lesion is performed with 3 - $10 \mathrm{~mm}$ margins, depending on the size and location of the tumour [7]. Mohs surgery is performed with the aim of tissue sparing and to have small percentage of local recurrence. Electric cauterization and curettage is performed in lesions that are $<5 \mathrm{~cm}$ in greatest diameter. Other modalities of treatment include Cryotherapy, Roentgen therapy, Laser therapy using $\mathrm{CO}_{2}$ laser, Interferon alpha therapy and application of 5 - Fluorouracil. Photodynamic therapy is a newer modality, in the tumour cells are first sensitized with methyl-amino levulinate and then irradiated with a light of $630 \mathrm{~nm}$ wavelength [6]

The choice of treatment for BCC is influenced by patient factors such as general fitness, coexisting medical conditions, and other factors such as patient choice, local availability of specialised services, and experience and availability of the surgeon [1]. The British Association of Dermatologists (BAD) [1] and the American Academy of Dermatology have established guidelines for the management of BCC [8], Luz., et al. [9] in 2013 gave an algorithm for the management of BCC (Figure 4).

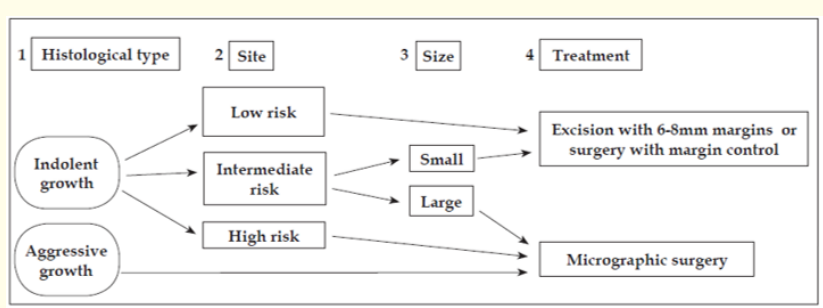

Figure 4 


\section{Conclusion}

We performed Mohs micrographic surgery, and achieved clear surgical margins at $1 \mathrm{~cm}$. A local advancement flap was used for closure of the defect.

The metastatic rate of BCC ranges from $0.0028 \%$ to $0.55 \%$. A recurrence rate of less than one third in the first year, $50 \%$ in the second year and $66 \%$ within 3 years was noted [10].

\section{Bibliography}

1. Telfer NR., et al. "Guidelines for the management of basal cell carcinoma". British Journal of Dermatology 159.1 (2008): 3548.

2. Kumar S., et al. "A Study of Basal Cell Carcinoma in South Asians for Risk Factor and Clinicopathological Characterization: A Hospital Based Study". Journal of Skin Cancer (2014): 173582.

3. Newman JC and Leffell DJ. "Correlation of Embryonic Fusion Planes with the Anatomical Distribution of Basal Cell Carcinoma". Dermatologic Surgery 33.8 (2007): 957-965.

4. Deshpande. "Methylation pattern of retrotransposons: Biomarker for human cancer". Journal of Datta Meghe Institute of Medical Sciences University 13.1 (2020).

5. Saikia U., et al. "Nonmelanoma skin cancers: An Indian perspective". Indian Journal of Dermatopathology and Diagnostic Dermatology 1.2 (2014): 55-62.

6. Dourmishev L., et al. "Clinical variants, stages, and management of basal cell carcinoma”. Indian Dermatology Online Journal 4.1 (2013): 12-17.

7. Gulleth Y., et al. "What is the best surgical margin for a Basal cell carcinoma: a meta-analysis of the literature". Plastic and Reconstructive Surgery 126.4 (2010): 1222-1231.

8. Drake RL., et al. "Gray's anatomy for students". Richard L. Drake, A. Wayne Vogl, Adam W.M. Mitchell-illustrations by Richard Tibbitts and Paul Richardson photographs by Ansell Horn. Fourth edition. United States: Philadelphia, PA: Elsevier (2020).

9. Luz FB., et al. "Surgical treatment of basal cell carcinoma: an algorithm based on the literature". Anais Brasileiros de Dermatologia 90.3 (2015): 377-383.

10. Rowe DE., et al. "Long-term recurrence rates in previously untreated (primary) basal cell carcinoma: implications for patient follow-up". Journal of Dermatologic Surgery and Oncology 15.3 (1989): 315-328

\section{Assets from publication with us}

- Prompt Acknowledgement after receiving the article

- Thorough Double blinded peer review

- Rapid Publication

- Issue of Publication Certificate

- High visibility of your Published work

Website: https://www.actascientific.com/

Submit Article: https://www.actascientific.com/submission.php Email us: editor@actascientific.com

Contact us: +919182824667 